Article

\title{
Assessment of the Lower Carboniferous-Devonian Aquifer as a Source of Geothermal Energy in the Silesian-Kraków Region (Poland)
}

\author{
Antoni Barbacki ${ }^{1, *}$, Maciej Miecznik ${ }^{1}\left[\right.$, Barbara Tomaszewska ${ }^{2}$ and Robert Skrzypczak ${ }^{1}(\mathbb{C}$ \\ 1 Mineral and Energy Economy Research Institute, Polish Academy of Sciences, 31-261 Kraków, Poland; \\ miecznik@min-pan.krakow.pl (M.M.); robskrzy@min-pan.krakow.pl (R.S.) \\ 2 Faculty of Geology, Geophysics and Environmental Protection, AGH University of Science and Technology, \\ 30-059 Kraków, Poland; barbara.tomaszewska@agh.edu.pl \\ * Correspondence: barbacki@min-pan.krakow.pl
}

Received: 28 October 2020; Accepted: 14 December 2020; Published: 18 December 2020

\begin{abstract}
In view of the disastrous air pollution in the Silesian-Kraków region, reducing emissions from the combustion of conventional fuels is a particularly important issue. Geothermal energy is among the clean and renewable sources of heat that could be used to this end, for instance for recreation or space heating purposes. However, its use in the region is limited, mainly due to insufficient knowledge of the characteristics of the geothermal complexes present. Mesozoic complexes in the region have much smaller energy resources compared to the Polish Lowlands or Podhale, but Paleozoic ones, mainly the Lower Carboniferous and Devonian, offer realistic prospects for energy extraction. The aim of this study was to identify geothermal conditions within the Lower Carboniferous-Devonian complex, primarily in terms of using the waters present there for space heating purposes. The prospective zones identified and indicated during the research are only forecasts, and their actual utility can only be confirmed after new wells have been drilled to verify the actual conditions.
\end{abstract}

Keywords: geothermal energy; Paleozoic aquifer; exploration perspectives; Silesian-Kraków region; Poland

\section{Introduction}

According to the ranking compiled by the European Environment Agency (EEA), the ten most polluted cities in Europe in 2020 included six from Poland. In the Kraków region, these are Kraków and Nowy Sacz, and in the Silesia region, these are Katowice, Sosnowiec, Zabrze and Gliwice. The main emission sources, apart from industry and transport, include electricity and heat production. In this respect, the replacement of coal-based sources of energy, which are widely used in the area, with renewable ones would be a particularly important and necessary development. In addition to solar, wind and hydropower, geothermal energy also offers real prospects for reducing pollution, but it is difficult to assess the feasibility of utilizing geothermal resources in the region due to its particularly complex geology.

Owing to the direct contact between the Kraków and Silesian regions, for the purposes of assessing their geothermal potential these two regions have been treated jointly in our analysis as the Silesian-Kraków region, but we have limited ourselves to the part which includes four of the aforementioned cities: Katowice, Sosnowiec, Kraków and Nowy Sącz. The area thus selected measures around $120 \times 100 \mathrm{~km}$ and has a surface area of approximately $12,000 \mathrm{~km}^{2}$ (Figure 1). 


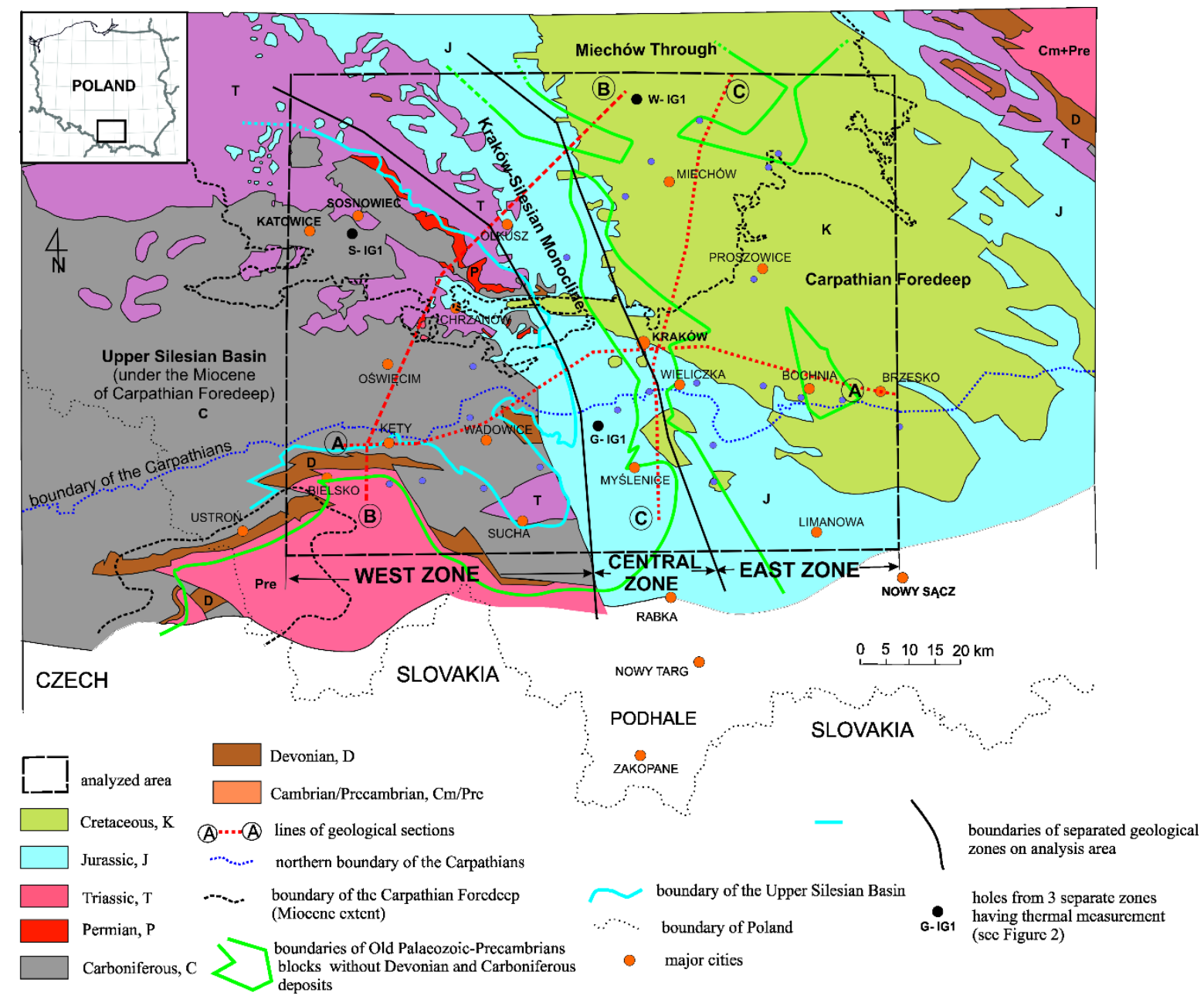

Figure 1. Geological map of analyzed area without Quaternary formations (after [1], modified).

In a more regional perspective, prospects related to the use of geothermal energy in this area have been presented in numerous publications. These concerned the assessment of thermal water resources and conditions for their presence in the Polish Lowlands [2-5], the Carpathian Foredeep [6], the Western Carpathians [7] and the Małopolska region [8,9]. Characteristics of thermal water aquifers in the northern part of the area analyzed (excluding the Silesian and Carpathian zones) have been the subject of numerous studies [10-14]. On the other hand, the prospects for geothermal energy generation in the Upper Silesian Basin were discussed in [15-23].

Even a cursory review of the aforementioned studies demonstrates that in the Silesian-Kraków region, geothermal energy resources appear quite modest in comparison with those of the Polish Lowlands or Podhale. Although Mesozoic (Cenomanian, Middle and Upper Jurassic) formations exhibit high groundwater flow rates, the depths they reach does not allow water temperatures above $60{ }^{\circ} \mathrm{C}$ to be achieved (see Figure 2). Therefore, these waters are mainly suitable for recreational and balneotherapy use. In the Carpathian zone, Mesozoic formations are present in high temperature zones (see Figures 1 and 3), but the water flow rates observed are significantly lower there. The situation is similar with Miocene formations: in the Carpathian Foredeep, these locally exhibit favorable reservoir parameters but low temperatures (up to $30^{\circ} \mathrm{C}$ ), while in the sub-Carpathian zone, temperatures rise but at the expense of decreasing flow rates [10] (see Figure 3). 


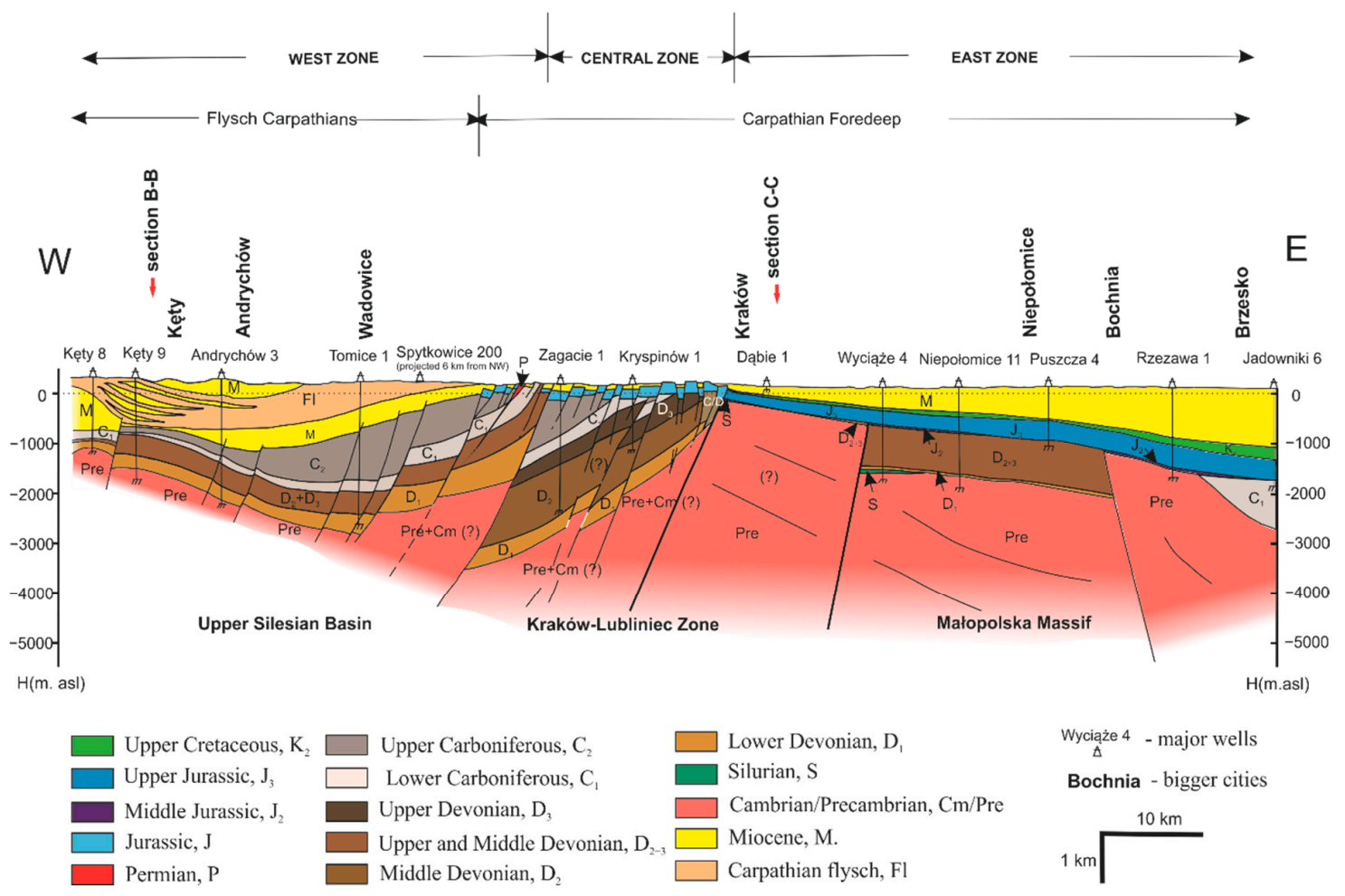

Figure 2. Schematic A-A geological cross-section through the area of analysis (based on PGNiG SA and PIG borehole data, CBDG PIG-PIB portal and according to $[10,11,13]$-location in Figure 1).

The utilization of thermal waters in the studied region is modest and mainly limited to recreational (Poręba Wielka near Rabka - waters of the Carpathian aquifer) and balneotherapy (Ustron-waters of the Devonian aquifer, Rabka — waters of the Carpathian aquifer) applications. Only in Słomniki are the waters of the Cenomanian aquifer (Middle Cretaceous) being used for space heating purposes, but owing to their low temperatures $\left(17^{\circ} \mathrm{C}\right)$, the system is based on heat pump technology. Despite their considerable flow rates, thermal waters present in Mesozoic reservoirs in the area outside the Carpathians should also be treated as suitable mainly for use in recreation owing to their temperature range. It is only to the east of Brzesko (Jadowniki 6 well, Figure 2) that waters of Mesozoic aquifer reach temperatures of up to $60^{\circ} \mathrm{C}$.

According to the studies conducted to date [24], the Carpathian flysch complex is also unpromising from the point of view of extracting thermal waters in significant quantities and at high temperatures. In the vicinity of the area analyzed, only one well (in the Rabka-Poreba Wielka area) achieved a water flow rate of around $12 \mathrm{~m}^{3} / \mathrm{h}$; water mineral content was $22 \mathrm{~g} / \mathrm{L}$ and the temperature at the wellhead was $42^{\circ} \mathrm{C}$, which enabled its direct use in recreation.

On the other hand, older Paleozoic and Precambrian formations, due to their extremely unfavorable reservoir parameters confirmed by the absence of water in almost every well in the region [10], should be considered unpromising from the point of view of geothermal use. However, this does not mean a complete lack of prospects, since very little exploration has been conducted to date with respect to the aquifer in question.

To sum up, as concerns the use of geothermal energy in the area in question not only for recreation or balneotherapy but also for space heating purposes (which is a precondition for reducing existing pollutant emissions), only the Carboniferous-Devonian complex offers real prospects for such use. 


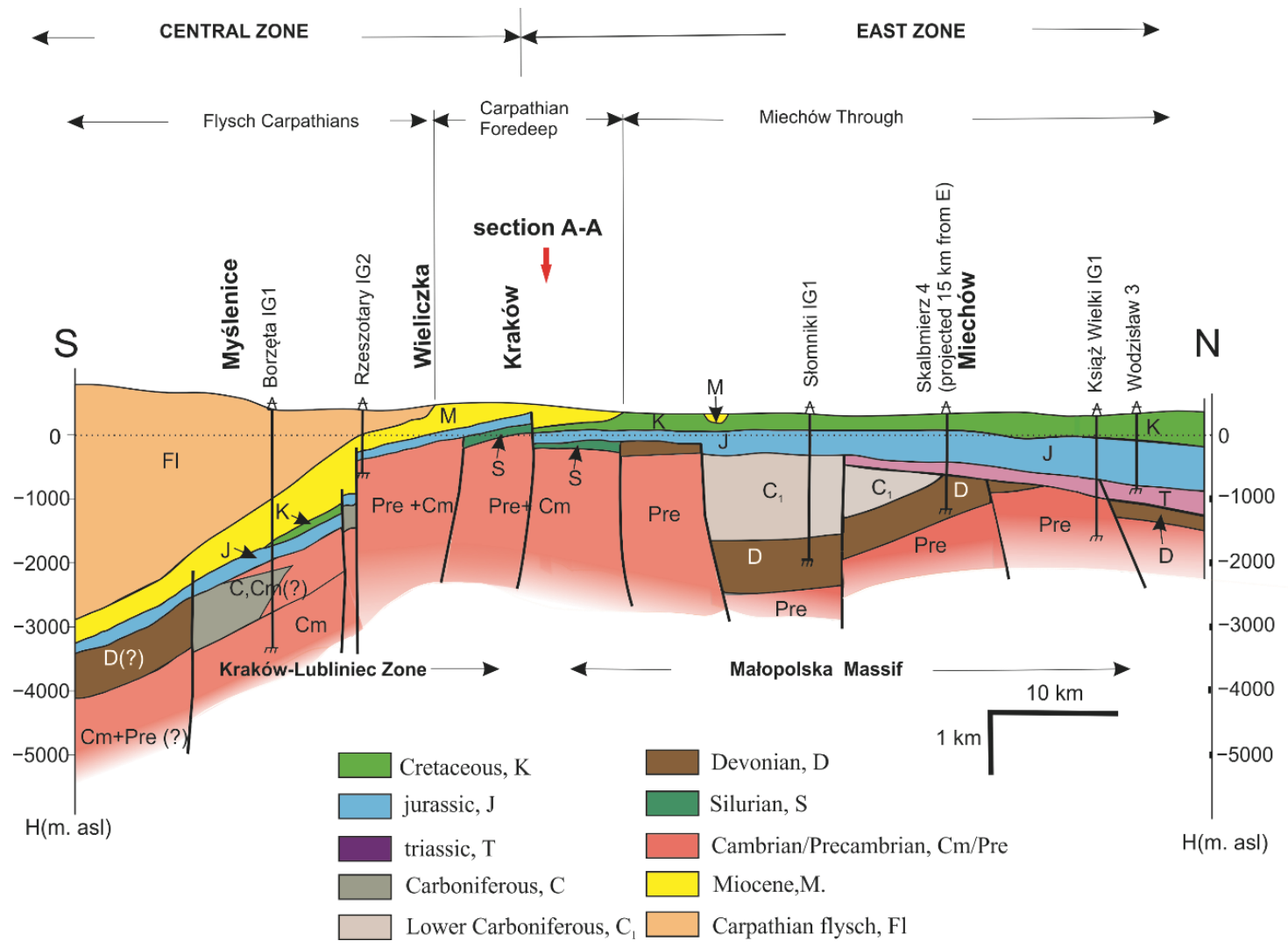

Figure 3. Schematic $\mathrm{C}-\mathrm{C}$ geological cross-section through the area of analysis (based on PGNiG SA and PIG borehole data, CBDG PIG-PIB portal and according to [1,6]—location in Figure 1).

To date, a two-fold approach has been adopted with respect to analyzing this complex from the point of view of its geothermal potential: it has been analyzed as a clastic Upper Carboniferous aquifer and as a carbonate Carboniferous-Devonian aquifer [6,7]. Due to its low flow rates, high mineral content of the water, non-renewable resources and water drainage by hard coal mining, the clastic Upper Carboniferous aquifer cannot be viewed as a prospective source of thermal waters [15,21]. The case is similar with the clastic Lower Carboniferous and Lower Devonian aquifer, mainly due to poor reservoir parameters [6,7]. On the other hand, within Carboniferous-Devonian complex the greatest hopes for extracting useful thermal waters are associated with carbonate formations of the Lower Carboniferous and carbonate formations of the Middle and Upper Devonian.

However, this study analyzes the Lower Carboniferous and Devonian complex as one aquifer without excluding the clastic series of the Lower Carboniferous and Lower Devonian. This is mainly due to the ambiguity of stratigraphic distinctions presented in publications and archival borehole data, but also due to the fact that in the area analyzed, thermal water inflows were recorded both in Lower Carboniferous clastic formations (e.g., Słomniki, Figure 3) and in Lower Devonian ones (Niepołomice, Figure 2).

Analyzing the data presented in the publications on the carbonate Carboniferous-Devonian aquifer $[6,7,10]$, it can be observed that it does not look overly promising in terms of the flow rates achievable. In general, it is estimated that maximum well flow rates will not exceed $50 \mathrm{~m}^{3} / \mathrm{h}$ and the average flow rate $20 \mathrm{~m}^{3} / \mathrm{h}$. At the same time, zones can be observed where these rates increase dramatically, sometimes exceeding $100 \mathrm{~m}^{3} / \mathrm{h}$ (the Słomniki area, Figure 3) despite low grain porosity and permeability (Table 1). This reflects the dominant role of fracturing zones caused by tectonic or dolomitization processes in these areas. Groups of zones with increased water flow rates can also be observed in the vicinity of Bielsko (the Devonian aquifer which has been developed in Ustroń) and 
Bochnia. These zones are adjacent to Cambrian-Precambrian blocks where Carboniferous-Devonian formations were removed as a result of tectonic processes and erosion.

Table 1. Selected hydrogeothermal parameters of the "Lower Carboniferous-Devonian" aquifer in wells with the inflow of thermal waters in the area of the Silesia-Krakow region (after well data derived from Polish Geological Institute, PGNiG and [5-7,9]).

\begin{tabular}{|c|c|c|c|c|c|c|}
\hline \multirow[b]{2}{*}{ No of wells } & \multirow[b]{2}{*}{ Name of Well } & \multirow[b]{2}{*}{$\begin{array}{l}\text { Depth } \\
\text { Interval of } \\
\text { Aquifer in } \\
\text { Well } \\
\text { (m) }\end{array}$} & \multirow[b]{2}{*}{$\begin{array}{l}\text { Temperature } \\
\text { Range of } \\
\text { Aquifer } \\
\left({ }^{\circ} \mathrm{C}\right)\end{array}$} & \multirow[b]{2}{*}{$\begin{array}{c}\text { Water } \\
\text { Mineralization } \\
\text { TDS in the Top } \\
\text { of Aquifer } \\
(\mathrm{g} / \mathrm{L})\end{array}$} & \multicolumn{2}{|c|}{ Reservoir Parameters } \\
\hline & & & & & $\begin{array}{l}\text { Porosity in } \\
\text { the Top of } \\
\text { Aquifer } \\
(\%)\end{array}$ & $\begin{array}{c}\text { Permeability } \\
\text { in the Top of } \\
\text { Aquifer } \\
\text { (mD) }\end{array}$ \\
\hline \multicolumn{7}{|c|}{ Thermal waters qualified for balneotherapy and recreation } \\
\hline 1 & Ustroń IG-3 & $1040-1740$ & $32-55$ & $\sim 130$ & $0.1-4.0$ & $0.1-1.0$ \\
\hline 2 & Jaworze IG-2 & $1430-1650$ & $40-50$ & 110 & $0.1-5.0$ & $0.1-6.0$ \\
\hline 3 & Bielsko 2 & $1120-1360$ ** & $35-55^{*}$ & 130 & $0.1-5.0$ & $0.1-6.0$ \\
\hline 4 & Kęty 7 & $970-1670$ & $30-50$ & $\sim 130$ & $0.1-5.0$ & $0.1-6.0$ \\
\hline 5 & Ketty 8 & $1040-1440$ & $32-40$ & $\sim 80$ & $0.1-6.0$ & $0.1-6.0$ \\
\hline 6 & Kety 9 & $1070-1800$ & $33-55$ & 107 & $0.1-5.0$ & $0.1-6.0$ \\
\hline 8 & Andrychów 4 & $1670-2380$ & $50-65$ & 145 & $0.1-4.0$ & $0.1-5.0$ \\
\hline 17 & Wyciaże 4 & $670-1720$ & $24-55$ & $\sim 13$ & $\sim 5.0$ & $\sim 10.0$ \\
\hline 18 & $\begin{array}{c}\text { Niepołomice } \\
11\end{array}$ & 890-1880 & $28-57$ & $\sim 5$ & $\sim 4.0$ & $\sim 9.0$ \\
\hline 19 & Puszcza 4 & $1100-1200$ ** & $35-45^{*}$ & $\sim 10$ & $\sim 5.0$ & $\sim 10.0$ \\
\hline 20 & Puszcza 14 & $800-1560$ & $26-45$ & $\sim 5$ & $\sim 5.0$ & $\sim 10.0$ \\
\hline 21 & Cikowice 1 & $1280-1470$ ** & $38-55^{*}$ & $\sim 15$ & $\sim 5.0$ & $\sim 10.0$ \\
\hline 22 & Łapczyca 2 & $1480-1800$ & $42-55$ & $\sim 20$ & $\sim 4.0$ & $\sim 8.0$ \\
\hline \multicolumn{7}{|c|}{ Thermal waters qualified for space heating (water temperature above $70^{\circ} \mathrm{C}$ ) } \\
\hline 24 & Grobla 33 & $1020-1210$ ** & $31-90 *$ & $\sim 100$ & $\sim 12.0$ & $\sim 100$ \\
\hline 25 & Grobla 28 & $1110-3010$ ** & $35-90 *$ & $\sim 110$ & $\sim 8.0$ & $\sim 70.0$ \\
\hline 26 & Mniszów 16 & $1160-3050$ ** & $36-90 *$ & $\sim 110$ & $\sim 8.0$ & $\sim 70.0$ \\
\hline 27 & Słomniki IG-1 & $640-2330 * *$ & $23-80$ * & $\sim 25$ & $\sim 5.0$ & $\sim 5.0$ \\
\hline 32 & $\begin{array}{l}\text { Weegrzynów } \\
\text { IG-1 }\end{array}$ & $1060-3100$ ** & $32-100$ * & $\sim 2$ & $\sim 7.0$ & 24.5 \\
\hline 36 & $\begin{array}{l}\text { Spytkowice } \\
200\end{array}$ & $1650-3180$ ** & $55-100$ * & $\sim 180$ & $0.1-3.0$ & $0.1-1.0$ \\
\hline 40 & Jadowniki 6 & $1890-2120$ ** & $57-80$ * & $\sim 70$ & $\sim 5.0$ & $\sim 10.0$ \\
\hline 43 & $\begin{array}{l}\text { Głogoczów } \\
\text { IG-1 }\end{array}$ & $1450-2470$ & $40-70$ & $\sim 100$ & $\sim 5.0$ & $\sim 10.0$ \\
\hline 44 & Mogilany 1 & $460-2500 * *$ & $20-70$ * & $\sim 25$ & $\sim 4.0$ & $\sim 8.0$ \\
\hline
\end{tabular}

The aim of the study was to indicate and identify such zones as promising from the point of view of producing thermal waters with temperatures and flow rates which could be used not only in balneotherapy and recreation but mainly in space heating.

\section{Geological and Hydrogeological Setting}

The area analyzed has a very complex geological structure. Structures deriving from the Alpine orogeny that are present here (Figure 1) overlie one another as shown in the geological cross-section in Figure 3. Flysch Carpathian structures are overlaid on the Miocene formations of the Carpathian Foredeep, and Foredeep formations, in turn, are overlaid on the Mesozoic (Cretaceous, Jurassic, Triassic) formations of the Miechów Trough. On the western side of the Miechów Trough, there is another 
Alpine structure-the Kraków-Silesian Monocline. This is an extension of the Miechów Trough to the west, already without Cretaceous formations (Figures 1 and 4). In the basement of the Alpine structures, there are three Variscan and Caledonian structures: the Upper Silesian Basin, the Kraków-Lubliniec Zone and the Małopolska Massif. It is assumed that the Kraków-Lubliniec Zone separating the Upper Silesian Basin and the Małopolska Massif is an eroded orogen formed as a result of Caledonian and Variscan orogeny $[25,26]$. The extent of this orogen to the south, under the Carpathian overthrust nappes, is unknown, although it probably reaches as far as the Pieniny Klippen Belt (see Figure 3). Characteristic elements of this zone are Old Paleozoic-Precambrian tectonic blocks devoid of Devonian and Carboniferous formations, which form, among others, a natural border between this zone and the Małopolska Massif (Figure 1).

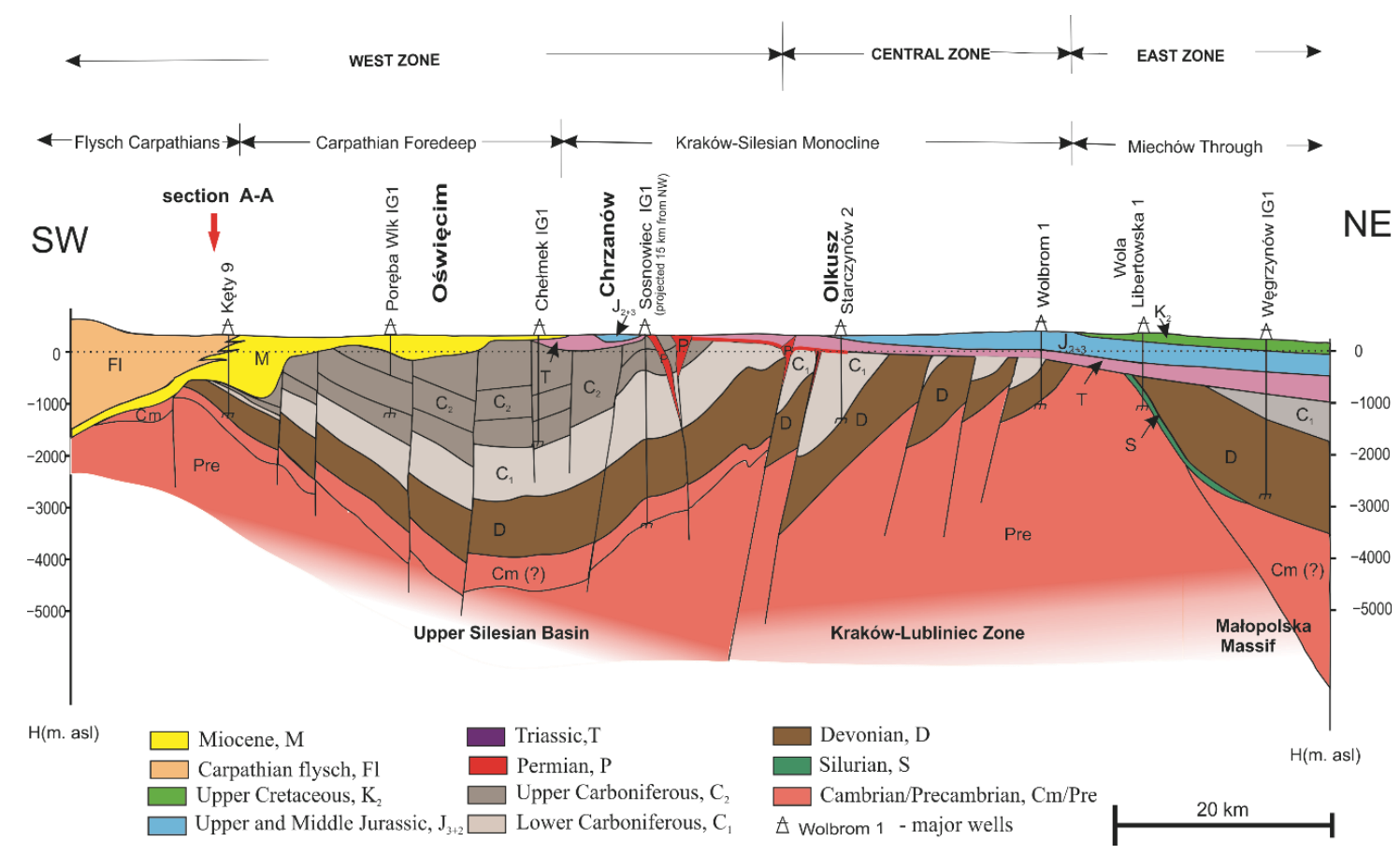

Figure 4. Schematic B-B geological cross-section through the area of analysis (based on PGNiG SA and PIG borehole data, CBDG PIG-PIB portal and according to $[1,7,27]$-location in Figure 1).

The Carboniferous-Devonian complex analyzed is a Paleozoic component of all the three aforementioned Variscan-Caledonian structures, but it exhibits peculiar lithological, tectonic and hydrogeological characteristics within these structures [6,7]. For this reason, the study area was divided into three zones: the western zone-covering the eastern part of the Upper Silesian Basin, the central zone-covering the area of the Kraków-Lubliniec Zone and the eastern zone—covering the area of the Małopolska Massif (Figures 1-4).

Apart from the differences in structure visible in the geological cross-sections presented, there are also clear differences in complex lithology.

Lower Carboniferous formations in the western zone are made up of crinoid limestones and flysch Culm formations; the central zone is made up of carbonate limestone, shale and flysch formations; and the eastern zone is made up of limestones, marls and mudstones.

Devonian formations in the western zone, on the other hand, include Lower Devonian sandstones and Middle and Upper Devonian dolomites and limestones. In the central zone, Devonian formations are clay-sandstone Lower Devonian formations of the "Old Red" type, thick-banked Middle Devonian limestones and Upper Devonian reef limestones. In the eastern zone, Devonian formations are represented by "Old Red" type Lower Devonian formations, dolomites and dolomitic limestones of the Middle Devonian, and Upper Devonian limestones, marls and mudstones. 
The three zones delimited within the Silesian-Kraków region also differ in terms of their hydrogeological and thermal conditions.

In the western zone (the eastern part of the Upper Silesian Basin), the Lower CarboniferousDevonian complex generally exhibits poor reservoir parameters, which was determined, inter alia, in the Sosnowiec IG-1 well (Figure 1). Within this zone, filtration coefficients ranged from $10^{-8}$ to $10^{-10} \mathrm{~m} / \mathrm{s}$ and flow rates did not exceed $1 \mathrm{~m}^{3} / \mathrm{h}[15,16]$. However, on a local scale, this complex may exhibit favorable reservoir parameters, as observed, e.g., in the area of Bielsko, Kety, Ustron and Sucha, where water flow rates reached $20 \mathrm{~m}^{3} / \mathrm{h}$. These are not high flow rates, but well stimulation, e.g., through acidizing, could significantly increase them, as was the case in, e.g., carbonate complexes in Podhale region [27]. The waters occurring here are brines with mineral content ranging from 100 (Kęty area) to $180 \mathrm{~g} / \mathrm{L}$ (Sosnowiec, Spytkowice areas), and mineral content increases with depth as a rule.

Temperature variation within the complex in question in the western zone is best illustrated by the Sosnowiec IG-1 well (Figure 7A) located within the Upper Silesian Basin (S-IG1, Figure 1) [23]. The Lower Carboniferous-Devonian complex occurs here within the depth interval of 1370-3150 m (from -1120 to $-2900 \mathrm{~m}$ a.s.l.). The temperature of the top surface of the complex is about $57^{\circ} \mathrm{C}$, and the temperature of the bottom surface is about $97^{\circ} \mathrm{C}$. The temperature of $70^{\circ} \mathrm{C}$ occurs already at a depth of $1870 \mathrm{~m}$, so this is a positive anomaly compared to the rest of the country. Surface heat flow density is about $70 \mathrm{~mW} / \mathrm{m} 2$ [18], which can be considered average for the entire western zone, and the mean geothermal gradient varies from 2.0 to $4.4^{\circ} \mathrm{C} / 100 \mathrm{~m}$.

In the central zone (the Kraków-Lubliniec Zone), the complex was subject to dramatic tectonic changes in the Variscan orogeny, which led to the disintegration of its layers, a significant increase in their inclination angle when the orogen was uplifted and the formation of tectonic overthrusts where Devonian formations often overlie those of the Lower Carboniferous (Figures 2 and 4). Even in wells situated in close proximity to one another, the top layer of the Lower Carboniferous-Devonian complex may be located at very different depths, and unconformable Devonian formations are sometimes present above Lower Carboniferous ones. Figures 2, 4 and 5 show that the top surface of the complex in this zone is located at relatively small depths, but the formations themselves can reach very large apparent thicknesses (e.g., in the Kryspinów 1 well, the top of the complex is at $-10 \mathrm{~m}$ a.s.l., while its bottom is at a depth of around $-2000 \mathrm{~m}$ a.s.l., Figure 2). In this zone, favorable reservoir parameters occur mainly in the carbonate formations of the complex present in shallow near-surface zones. In the Kryspinów 1 well, water flow rates from Lower Carboniferous formations amounted to around $20 \mathrm{~m}^{3} / \mathrm{h}$, and in the area of Krzeszowice ( $15 \mathrm{~km}$ to the west of Kraków) they reached around $200 \mathrm{~m}^{3} / \mathrm{h}$; however, those were cold $\left(14-17^{\circ} \mathrm{C}\right)$ and fresh waters. Filtration coefficients here ranged up to $1.3 \cdot 10^{-5} \mathrm{~m} / \mathrm{s}$.

In the Carpathians, where the Kraków-Lubliniec Zone underthrusts Miocene and flysch formations (Figure 3), water from Lower Carboniferous formations was found, among others, in the Głogoczów IG-1 well (Figure 1, Table 1) with a maximum porosity of $21 \%$ and a maximum permeability of about $90 \mathrm{mD}$ (Table 1 gives values for the top surface of the aquifer). However, the average porosity of Lower Carboniferous formations in the area of the Carpathians is around $8 \%$ and the average permeability is $10 \mathrm{mD}$ [28,29]. Local zones with higher flow rates are probably associated with fracturing zones near tectonic dislocations. Carbonate Devonian formations in the Carpathians exhibit slightly larger reservoir parameter values: the range of porosity values is $0-17 \%$ and permeability ranges from 0 to $125 \mathrm{mD}$ (for instance in the Mogilany 1 well: porosity $0.3-13 \%$, permeability $0-6 \mathrm{mD}$, location on Figures 5 and 6). The mineral content of waters in this zone varies from about 0.5 (Kryspinów 1 well) to $180 \mathrm{~g} / \mathrm{L}$ in the Myślenice area (Głogoczów IG-1 well). 


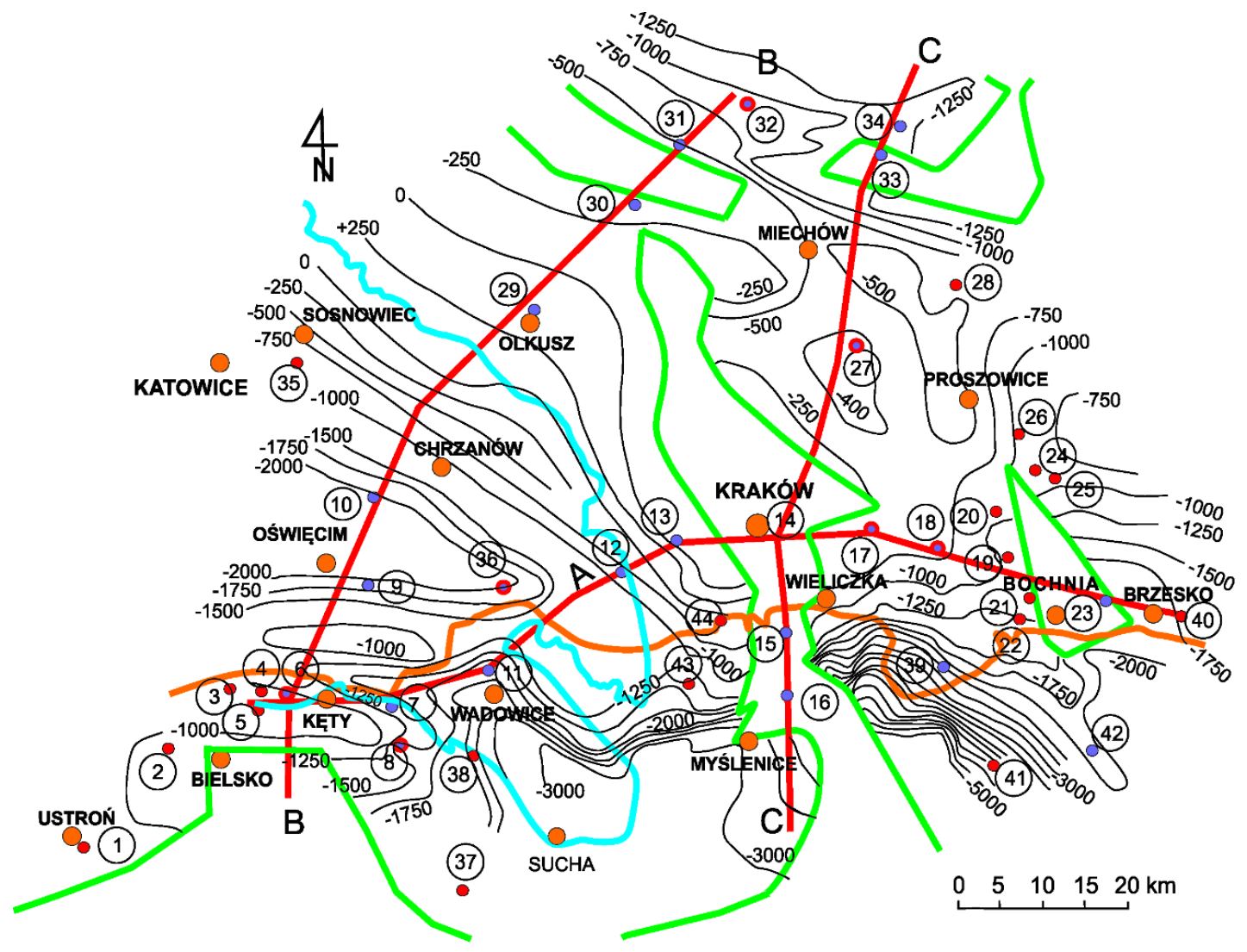

$\begin{array}{lll}\begin{array}{l}\text { isohypses of the top surface of Lower } \\ \text { Carboniferous-Devonian complex (m asl) }\end{array} & \begin{array}{l}\text { boundaries of Old Palaeozoic- } \\ \text { Precambrians blocks without } \\ \text { Devonian and Carboniferous } \\ \text { deposits }\end{array} \\ \begin{array}{l}\text { boundary of the Upper } \\ \text { Silesian Basin }\end{array} & \begin{array}{l}\text { lines of geological } \\ \text { sections }\end{array} \\ \text { major cities } & \begin{array}{l}\text { of thermal waters } \\ \text { wells with confirmed inflow } \\ \text { of thermal waters shown in } \\ \text { geological cross-sections }\end{array}\end{array}$

main analyzed wells:

\begin{tabular}{|c|c|c|c|}
\hline $\begin{array}{l}\text { ń IG3 } \\
\text { rze IG2 } \\
\text { ko } 2 \\
7 \\
8 \\
9 \\
9\end{array}$ & $\begin{array}{l}\text { 16. Borzęta IG1 } \\
\text { 17. Wyciąże } 4 \\
\text { 18. Niepołomice } 1 \\
\text { 19. Puszcza } 4 \\
\text { 20. Puszcza } 14 \\
\text { 21. Cikowice } 1 \\
\text { 22. Łapczyca } 2\end{array}$ & $\begin{array}{l}1 \\
3 \\
8 \\
16 \\
\text { IG1 } \\
\text { erz } 4 \\
\text { ów } 2 \\
1\end{array}$ & $\begin{array}{l}\text { 34. Wodzisław } 3 \\
\text { 35. Sosnowiec IG1 } \\
\text { 36. Spytkowice } 200 \\
\text { 37. Lachowice } 1 \\
\text { 38. Potrójna IG1 } \\
\text { 39. Liplas } 2 \\
\text { 40. Jadowniki } 6 \\
\text { 41. Tarnawa } 1 \\
\text { 42. Rajbrot } 2 \\
\text { 43. Głogoczów IG1 } \\
\text { 44. Mogilany } 1\end{array}$ \\
\hline
\end{tabular}

Figure 5. Structural map of the top surface of the Lower Carboniferous-Devonian complex in the analyzed part of the Silesia-Krakow region, well numbers as in Table 1 (based on PGNiG SA and PIG borehole data, CBDG PIG-PIB portal and according to $[5-7,9,10])$. 


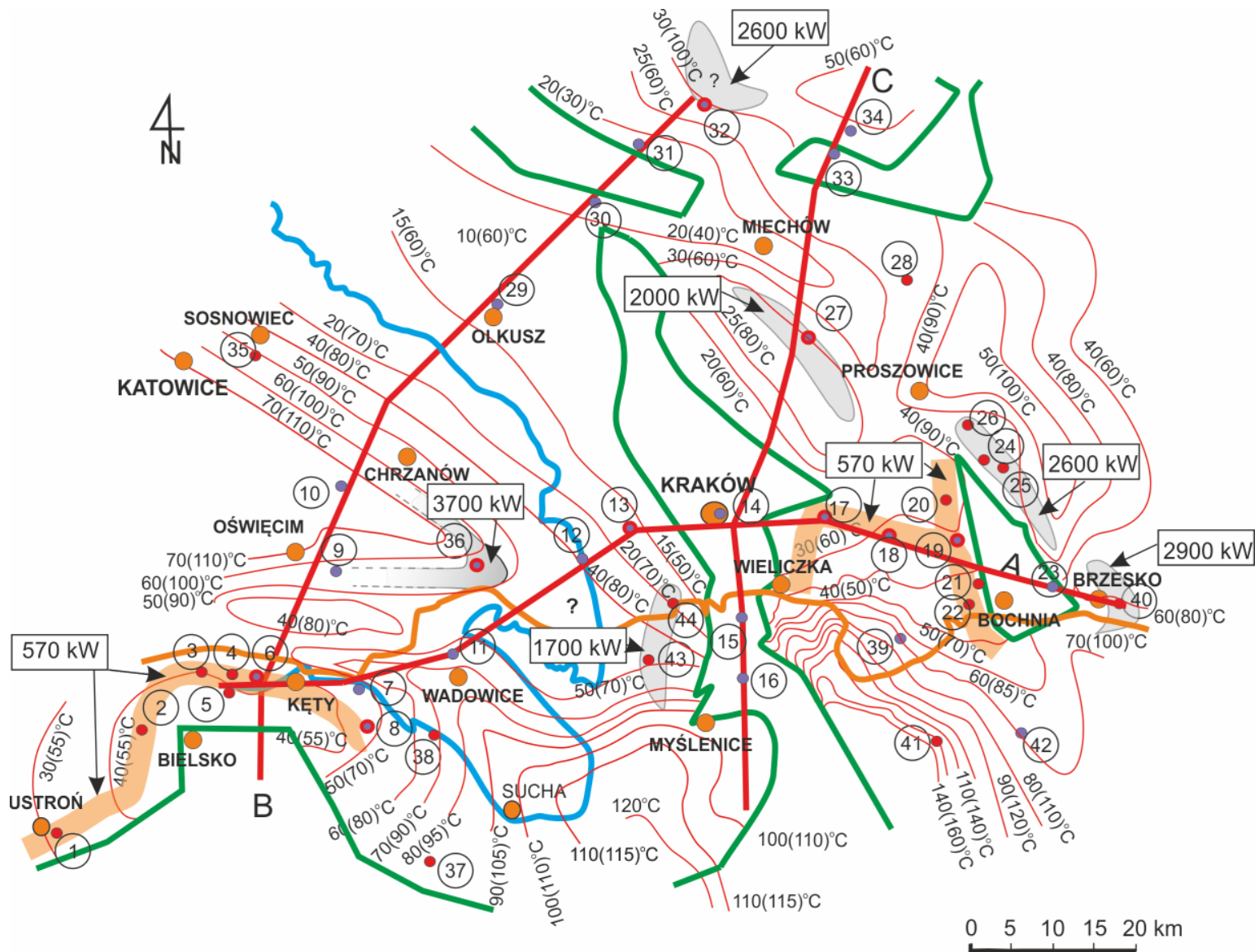

$\left(\begin{array}{ll}0 \\ \aleph^{0}\end{array}\right.$

geothermal perspective zones for space heating

geothermal perspective zones for balneotheraphy and recreation

$2900 \mathrm{~kW} \rightarrow$ hypothetical rated termal power from single geothermal instalation working in a doublet system

main analyzed wells:
1. Ustroń IG3
12. Zagacie 1
13. Kryspinów 1
2. Jaworze IG2
14. Dąbie 1
3. Bielsko
15. Rzeszotary IG2
5. Kęty 8
16. Borzęta IG1
6. Kęty 9
17. Wyciąże 4
7. Andrychów 3
18. Niepołomice 11
8. Andrychów 4
19. Puszcza 4
9. Poręba Wielka IG1
20. Puszcza 14
10. Chełmek IG1
11. Tomice 1
21. Cikowice 1
22. Łapczyca 2

23. Rzezawa 1
24. Grobla 33
25. Grobla 28
26. Mniszów 16
27. Słomniki IG1
28. Skalbmierz 4
29. Starczynów 2
30. Wolbrom 1
31. Wola Libertowska 1
32. Węgrzynów IG1
33. Książ Wielki IG1

34. Wodzisław 3

35. Sosnowiec IG1

36. Spytkowice 200

37. Lachowice 1

38. Potrójna IG1

39. Liplas 2

40. Jadowniki 6

41. Tarnawa 1

42. Rajbrot 2

43. Głogoczów IG1

44. Mogilany 1

Figure 6. Map of temperatures at the top/bottom surface of the Lower Carboniferous-Devonian complex in the analyzed part of the Silesia-Krakow region, well numbers as in Table 1 (based on PIG borehole data, and according to $[5-7,9,10])$.

Thermal conditions in the central zone are illustrated by the Głogoczów IG-1 well (Figure 7B) located in the Carpathians (G-IG1, Figure 1) [7]. Here, the Lower Carboniferous-Devonian complex occurs in the depth interval from 1450 to $2470 \mathrm{~m}$ (from -1140 to $-2160 \mathrm{~m}$ a.s.l.). The temperature of the 
top of the complex is about $50{ }^{\circ} \mathrm{C}$ and the temperature of its bottom is about $70{ }^{\circ} \mathrm{C}$. The temperature of $70^{\circ} \mathrm{C}$ occurs at a depth of $2470 \mathrm{~m}$. These are fairly typical conditions on a national scale. Surface heat flow density is about $50 \mathrm{~mW} / \mathrm{m}^{2}$ for the area outside the Carpathians [10] and about $70 \mathrm{~mW} / \mathrm{m}^{2}$ for the Carpathian area [24]. The mean geothermal gradient in the Carpathian area is about $2.4{ }^{\circ} \mathrm{C} / 100 \mathrm{~m}$ [24] and outside the Carpathians it is $2.3^{\circ} \mathrm{C} / 100 \mathrm{~m}$ [10]. These values are, therefore, much lower than in the western zone.

In the eastern zone (the Małopolska Massif), tectonic characteristics of the complex undergo a fundamental change and become much less dramatic (Figure 2). The complex occurs outside the Older Paleozoic and Precambrian blocks, reaching maximum thickness values along the Wegrzynów (Węgrzynów IG-1 well: 2040 m, Figures 1 and 7C, Table 1)-Słomniki (Słomniki IG-1 well: 1690 m, Figures 3 and 5, Table 1)-Grobla (Grobla 28 well: 1900 m, Figures 5 and 6, Table 1) line.

In this zone, the reservoir shows more favorable parameters than in the two zones discussed above; however, this mainly pertains to carbonate Devonian formations. The exception is the Słomniki region, where the carbonate formations of the Lower Carboniferous produced a free outflow of waters with a flow rate of $100 \mathrm{~m}^{3} / \mathrm{h}$, with a measured porosity of $2 \%$ and permeability of $0.1 \mathrm{mD}$. This shows that the fracturing phenomenon has a predominant influence on the value of reservoir parameters in the area. Additionally, the inflow of thermal brine with a flow rate of around $8 \mathrm{~m}^{3} / \mathrm{h}$ from Lower Carboniferous limestones in the Brzesko area (Jadowniki 6, Figures 2, 5 and 6, Table 1) was probably associated with the fracturing of the formations. In general, however, the Lower Carboniferous aquifer in the eastern zone-within the Miechów Trough, in the Carpathian Foredeep and within the Carpathian basement-is not promising from the point of view of geothermal use.

On the other hand, carbonate Devonian formations in the eastern zone look interesting. In the area of the Carpathian Foredeep, numerous cases of free outflow of waters from Devonian formations have been observed (in the following wells: Wyciąże 4, Niepołomice 11, Puszcza 14, Łapczyca 2, Figures 2 and 5, Table 1), which, however, were not present in the northern part of the zone (Miechów Trough region, Figure 1). Here, free outflows of water occurring at low permeability and porosity also underline the importance of the fracturing phenomenon. In the Carpathian Foredeep, total porosity values of Devonian formations usually range from 0 to $14 \%$ and permeability values range from 0 to $36 \mathrm{mD}$, while in the Carpathians, effective porosity values range from 0 to $10 \%$ and permeability values range from 1.2 to $2 \mathrm{mD}$ [28]. The mineral content of waters in the eastern zone ranges from about $3 \mathrm{~g} / \mathrm{L}$ in the Miechów Trough (the Wegrzynów IG-1 well, at a depth of $1350 \mathrm{~m}$ ) to about $250 \mathrm{~g} / \mathrm{L}$ in the Carpathian region (the Tarnawa 1 well, at a depth of $4800 \mathrm{~m} \mathrm{[3,6,30],} \mathrm{Figures} 5$ and 6).

Thermal conditions in the eastern zone are illustrated by the Wegrzynów IG-1 well (Figure 7C) located in the Miechów Trough (W-IG1, Figure 1) [31]. Here, the Lower Carboniferous-Devonian complex occurs at a depth interval from 1060 to $3100 \mathrm{~m}$ (from -780 to $-2820 \mathrm{~m}$ a.s.1.). The temperature of the top surface of the complex is about $37^{\circ} \mathrm{C}$ and the temperature of its bottom is about $85^{\circ} \mathrm{C}$. The temperature of $70^{\circ} \mathrm{C}$ occurs at a depth of $2440 \mathrm{~m}$. These are also typical conditions on a national scale. Surface heat flow density is around $50 \mathrm{~mW} / \mathrm{m}^{2}$ for the area outside the Carpathians [10] and around $60 \mathrm{~mW} / \mathrm{m}^{2}$ for the Carpathian area [24]. The mean geothermal gradient for the Carpathian area is about $2.4^{\circ} \mathrm{C} / 100 \mathrm{~m} \mathrm{[24]}$ and for the area outside the Carpathians it is $2.3^{\circ} \mathrm{C} / 100 \mathrm{~m}$ [10]. Thus, these values are similar to those observed in the central zone.

In Figure 7, it can be observed that irregularities in thermal profile curves clearly occur within the Lower Carboniferous-Devonian complex in three zones. This may result both from changes in thermal conductivity of rock formations and from thermal convection. Temperature distribution for the well in the eastern zone (within the Miechów Trough) exhibits the most regular, almost linear character. 
A

west zone
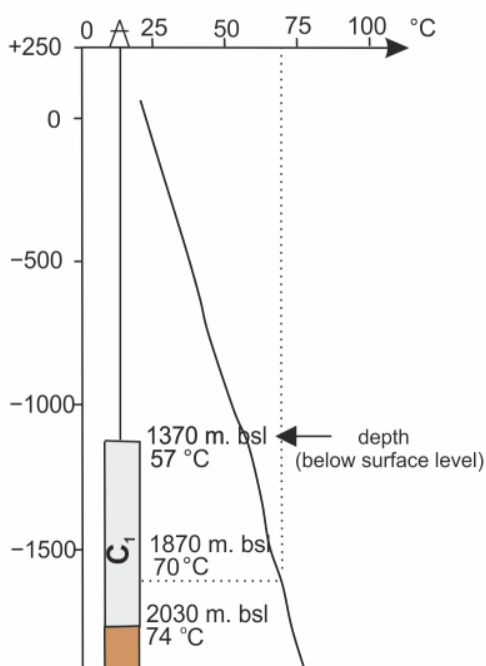

$-2000$

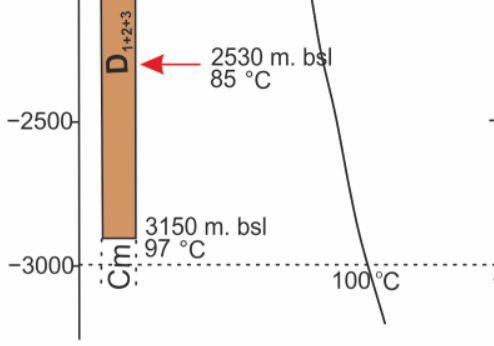

m. asl (above see level)

Sosnowiec IG1 well

$\operatorname{grad} \mathrm{T}^{\mathrm{sr}} \sim 2.7^{\circ} \mathrm{C} / 100 \mathrm{~m}$

$\operatorname{grad} \mathrm{T}^{\mathrm{D}+\mathrm{C}} \sim 2.6^{\circ} \mathrm{C} / 100 \mathrm{~m}$
B

central zone

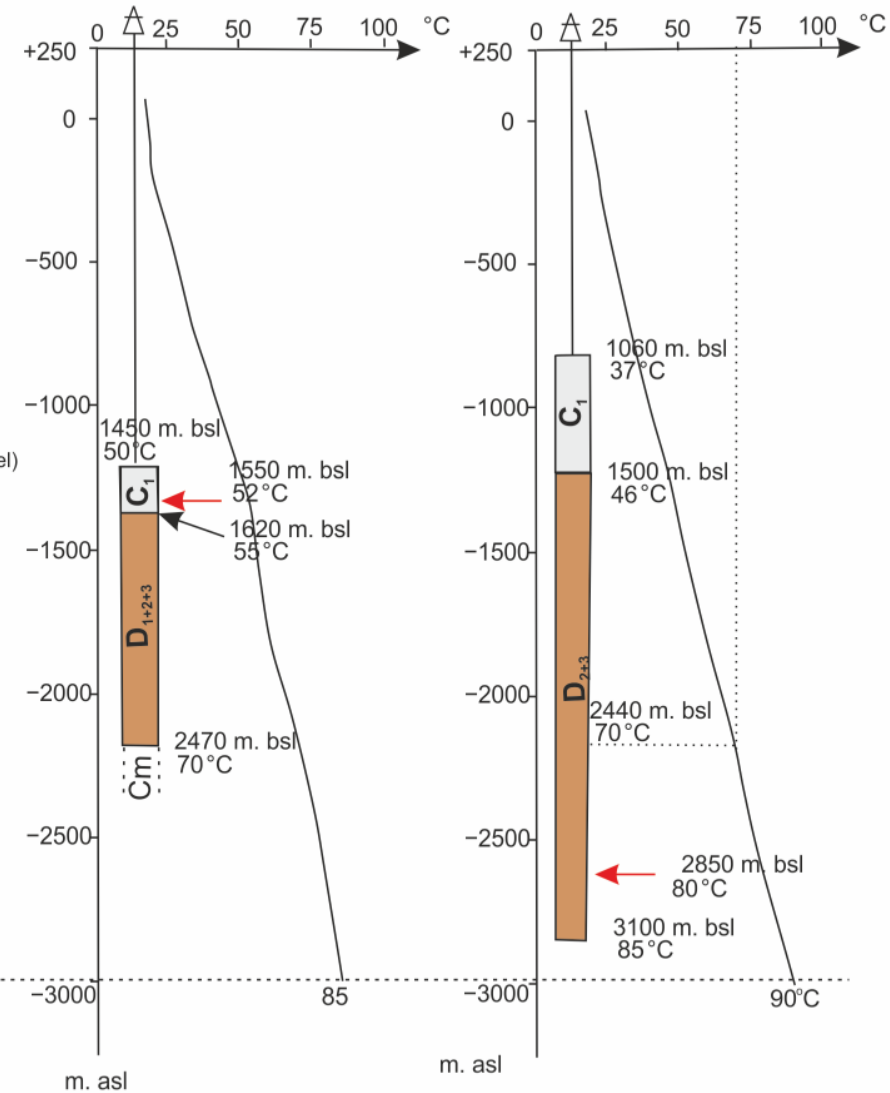

Głogoczów IG1 well

Węgrzynów IG1 well

$$
\operatorname{grad} \mathrm{T}^{\mathrm{sr}} \sim 2.4^{\circ} \mathrm{C} / 100 \mathrm{~m}
$$

$\operatorname{grad} \mathrm{T}^{\mathrm{sr}} \sim 2.4^{\circ} \mathrm{C} / 100 \mathrm{~m}$

$\operatorname{grad} \mathrm{T}^{\mathrm{D}+\mathrm{C}} \sim 2.1^{\circ} \mathrm{C} / 100 \mathrm{~m}$
C

east zone

Lower Carboniferous-Devonian aquifer; $\quad \mathrm{Cm}$ - Cambrian , $\mathrm{D}_{1+2+3}$ - Lower, Middle and Upper Devonian,

$\mathrm{D}_{2+3}$ - Middle and Upper Devonian, $\mathrm{C}_{1}$ - Lower Carboniferous

Figure 7. Stratigraphic column together with results of temperature-log interpretation in wells for each of the three separated zones: (A) west zone, (B) central zone, (C) east zone (according to [7,23,31], location in Figure 1).

\section{Materials and Methods}

The data presented above, related to the three analyzed research zones, indicate that geothermal prospects may be associated with fracturing phenomena and also with dolomitization and karst processes in carbonate formations. While dolomitization and karst zones are difficult to predict and locate, fracturing phenomena are most often associated with intense tectonic movements which are easier to locate.

Thus, we can formulate preliminary criteria which individual zones should meet to be considered prospective from the point of view of geothermal use:

- The zone is located in the vicinity of wells with recorded thermal water inflows;

- The zone is located on the rims of tectonic blocks, which are devoid of Carboniferous and

Devonian formations; 
- In the vicinity of the zone, signs of intensive tectonic movements can be observed;

- In adjacent geological wells, there are numerous dolomite layers which indicate the dolomitization processes;

- The complex exhibits considerable formation thicknesses.

Owing to the absence of relevant data, not all of the above criteria can be assessed when identifying prospective zones. However, the more of these criteria are met, the greater the chances are of a prospective zone being correctly identified.

In order to indicate prospective zones in terms of the aforementioned criteria, geological cross-sections (Figures 2-4) were drawn up alongside a structural map of the top surface of complex and a map of temperatures at the top/bottom surface of the complex. The geological cross-sections drawn up made it possible to assess geological structures with particular emphasis on tectonics of studied area. The structural map of the top surface (Figure 5) enables the assessment of the depth at which drilled wells should reach Lower Carboniferous or, where these are absent, Devonian formations. It also shows areas where this complex does not exist-in the areas of Old Paleozoic-Precambrian tectonic blocks. In terms of geothermal use, the most informative map is the temperature one (Figure 6), which shows the temperatures of the complex in its top surface (and in brackets in the bottom layer). The degree of variation in these values is an indicator of complex thickness. In the absence of measurement data, temperature values on the map were estimated on the basis of mean values of geothermal gradients in the three zones analyzed (after chapter 2).

The analyses carried out on the basis of the criteria adopted made it possible to identify potential prospective zones within the complex, the main criterion being the presence of wells with identified thermal water inflows, the presence of mentioned tectonic blocks and values of hydrogeothermal parameters. Locations of the wells with recorded thermal water inflows are shown on maps and geological cross-sections, while the hydrogeothermal parameters present within them are shown in Table 1. The prospective zones identified are shown in Figure 6, with thermal waters qualified for balneotherapy and recreation and thermal waters qualified for space heating being shown separately. A water temperature of $70^{\circ} \mathrm{C}$ was arbitrarily assumed as the minimum value for space heating purposes.

At this stage of research, due to lack of data and the specificity of the reservoir with extremely varied hydrogeological conditions, the assessment of available resources can only be indicative. The measure of resources can be the disposable rated thermal power obtainable from a single geothermal installation. If we assume that the installation works in a doublet system and the temperature of thermal water after heat recovery is $20^{\circ} \mathrm{C}$, rated thermal power output $P$ can be expressed as:

$$
P=Q \cdot \rho \cdot c_{p} \cdot(T-20)[\mathrm{W}]
$$

where $Q$-rated discharge of thermal water $(\mathrm{L} / \mathrm{s}), T$ - mean temperature $\left[{ }^{\circ} \mathrm{C}\right]$ of thermal waters between the temperature of the top and bottom of the aquifer (shown in Figure 6), $\rho$-water density $\left[\mathrm{kg} / \mathrm{m}^{3}\right]$, $c_{p}$-specific heat of water $[\mathrm{J} /(\mathrm{kgK})]$.

For geothermal perspective zones for balneotheraphy and recreation in the Ustron-Bielsko-Kẹty area and for Wieliczka-Bochnia area (see Figure 6), mean temperature $T$ is around $45^{\circ} \mathrm{C}$ and maximum discharge of wells can be estimated at around $20 \mathrm{~m}^{3} / \mathrm{h}$.

It was assumed that the effective use of thermal waters for heating purposes would take place when the yields of water would be at least $50 \mathrm{~m}^{3} / \mathrm{h}$. For geothermal perspective zones for space heating shown in Figure 6, such water yields may be achievable mainly in fracture zones (vide: Słomniki zone). Due to lack of data, it was arbitrarily assumed that in all these zones, yield of water is $50 \mathrm{~m}^{3} / \mathrm{h}$. Additionally, as mean temperatures $T$ the following was assumed: for Chrzanów zone (well 36, Figure 6) $-85^{\circ} \mathrm{C}$, for Mogilany zone (well 44)—50 ${ }^{\circ} \mathrm{C}$, for Brzesko zone (well 40 ) $-70{ }^{\circ} \mathrm{C}$, for Grobla zone (well 24-26) $-65^{\circ} \mathrm{C}$, for Słomniki zone (well 27) $-55^{\circ} \mathrm{C}$ and for Węgrzynów zone (well 32) $-65^{\circ} \mathrm{C}$. 
Thus, the calculated rated thermal powers are as follows: Ustron-Bielsko-Kety and WieliczkaBochnia 570 kW, Chrzanów 3700 kW, Mogilany 1700 kW, Brzesko 2900 kW, Grobla 2600 kW, Słomniki 2000 kW, Węgrzynów 2600 kW (shown on Figure 6).

However, it should be clearly stated that, as noted above, these are only indicative data and are more a form of energetic ranking than real evaluation of energy resources.

\section{Results and Discussion}

In the area analyzed, Variscan movements caused the folding and uplifting of the Carbon-Devonian complex in many places, and in the areas where the movements were the strongest and the complex reached its highest position, the subsequent intense erosion caused its complete disappearance. Therefore, Old Paleozoic-Precambrian tectonic blocks which are deprived of formations of this complex may be an indicator of intensive tectonic movements and of strongly fissured and fractured formations in their vicinity. This is confirmed by the location of numerous geological wells with thermal water inflows on the rims of the aforementioned blocks, among others in the Ustron-Bielsko-Kety and Bochnia-Brzesko areas and also to the east and southwest of Kraków (Figures 5 and 6; wells 17, 43 and 44) or in the Miechów area (Skalbmierz 4 well, Figure 3). The absence of this regularity with respect to tectonic blocks in the northern part of the study area probably results from less pronounced tectonic activity in the Miechów Trough and thus the formations being less fractured (e.g., wells 30, 31, Figure 6).

Wells with thermal waters are also present outside the rim zones related to the aforementioned tectonic blocks, but in these locations connections with zones of intensive tectonics can be noticed as well (Słomniki area, Figure 3; Niepołomice area, Figure 2). In these zones, the improvement in reservoir parameters could also have occurred as a result of dolomitization and karst processes, similarly as in the area of the Spytkowice 200 well in the Upper Silesian Basin where the entire Lower Carboniferous-Devonian complex is completely filled with a water (Figures 5 and 6). There is also a clear trend towards the complex reaching high thickness values (above $2000 \mathrm{~m}$ ) along the Wegrzynów IG-1-Słomniki IG-1- Grobla 28 line (Figures 3, 4 and 6, Table 1), and in these wells thermal waters were found.

Achieving temperatures of around $70{ }^{\circ} \mathrm{C}$ which make waters directly usable for space heating purposes (without the use of heat pumps) would require the exploration of deeper aquifers at depths below $2000 \mathrm{~m}$. The studies conducted to date $[2,6-8,10,15]$ indicate that the most favorable reservoir parameters in this area are shown by carbonate Carboniferous and Devonian formations. However, these parameters are not comparable to those in the extensive aquifers of the Lower Jurassic and Lower Cretaceous in the Polish Lowlands, and the complex is highly fragmented and tectonically disturbed. Despite the poor values of reservoir parameters in the regional context, a number of local zones have been found where these parameters are clearly better (with free outflows observed). Thus, the prospective zones indicated in the article are essentially local ones, even though some trends continue over long distances (e.g., along boundaries of tectonic blocks).

In all three zones studied, there is an almost complete lack of prospective zones for space heating purposes within the area of the Carpathians (Figure 6). This is due to the small number of wells drilled through the Carpathian massif (absence of data) and very complicated geological conditions (Figure 3). Only individual locations can be pointed out (the Lachowice and Tarnawa areas, wells 37 and 41, Figures 5 and 6), but the depth at which the top surface of the complex is situated (about $4000 \mathrm{~m}$ ) limits its use. On the boundary of the Carpathians, prospects for using the complex for space heating purposes are associated with the Głogoczów-Mogilany zone (wells 43 and 44, Figures 5 and 6) located in the vicinity of visible tectonic block. Due to the extremely complicated geological structure of the central study zone, this is the only location indicated in this area.

On the other hand, a fairly extensive prospective zone in the Carpathians has been identified in the western study zone, in the Bielsko region (Figure 6). However, the temperature conditions prevailing there $\left(30-55^{\circ} \mathrm{C}\right)$ allow the water to be used mainly for recreation and balneotherapy purposes. In the 
western study zone, in the area of the Upper Silesian Basin and in the Spytkowice 200 well (Figures 2, 5 and 6) borehole logging data [32] have shown that the carbonate and sandy Lower Carboniferous formations and sandy Upper Carboniferous formations are completely saturated with water. Since in this area, the bottom layer of the Carboniferous formation is located at a depth of around $2600 \mathrm{~m}$ (and the temperature is about $80^{\circ} \mathrm{C}$ according to Figure $7 \mathrm{~A}$ ), this zone has been indicated for potential space heating use (the Devonian formation was not explored). The lack of more extensive information on significant water inflows from this complex in this part of the Upper Silesian Basin makes it impossible to indicate other prospective zone locations [15].

In the eastern study zone (Małopolska Massif), prospective zones are grouped mainly around the tectonic block in the Bochnia-Brzesko-Proszowice area, and at the same time along the Brzesko-Proszowice-Miechów-Węrzynów line where complex thickness reaches considerable values (Figure 6). The top surface of the complex is situated at similar depths on the western and eastern side of the aforementioned block (with differences up to $200 \mathrm{~m}$, Figure 2); however, its bottom surface on the eastern side reaches a depth of over $3000 \mathrm{~m}$, and on the western side it is about $1600 \mathrm{~m}$ (see Table 1: well 20-Puszcza 14, and 25-Grobla 28, Figure 6). Hence, the western side with maximum temperatures of up to about $55{ }^{\circ} \mathrm{C}$ was indicated as prospective for recreation and/or balneotherapy purposes, and the eastern side with temperatures up to $90^{\circ} \mathrm{C}$ for space heating purposes (in the Grobla 28 well, brine was found at a depth of $2850 \mathrm{~m}$, but its flow rate was not measured). The aforementioned tectonic block is adjacent to the Kraków block, and although both blocks appear to be separate in Figure 6, their geological "cohesion" is visible in Figure 2. This is manifested, among others, by the fact that entire Devonian prospective zone present between the two blocks includes wells with recorded thermal water inflows from the Wyciazze, Niepołomice and Bochnia areas (Figures 2, 5 and 6).

Of the three remaining prospective zones within the eastern zone (around the Wegrzynów IG-1, Słomniki IG-1 and Jadowniki 6 wells, Figure 6), the Słomniki zone appears the most promising. While according to Figure 6, its location is not related to vicinity of the tectonic blocks discussed above, and such a connection cannot be ruled out when looking at geological structures on the cross-section shown in Figure 3 (Słomniki IG-1 well, thermal water inflows up to $100 \mathrm{~m}^{3} / \mathrm{h}$ ). Less attractive is the Jadowniki area where Lower Carboniferous carbonates produced water flows of about $8 \mathrm{~m}^{3} / \mathrm{h}$ from a depth of $2070 \mathrm{~m}$, and the Wegrzynów area where Devonian carbonates produced water flows of only about $3 \mathrm{~m}^{3} / \mathrm{h}$ from a depth of $2850 \mathrm{~m}$ (water temperature around $80{ }^{\circ} \mathrm{C}$ ).

In terms of energy, according to determined values of disposable rated thermal power obtainable from geothermal installation, the Chrzanów and Brzesko zones are the most favorable, although these are only indicative data.

In order to make the thermal power ratings more realistic, it would be necessary to reinterpret the well-logs data and perform a multivariate assessment of discharge of the aquifer in perspective zones based on data from wells located in these area. Correct evaluation of temperatures and discharges of wells is important here. The presented assessment of the temperature conditions is quite reliable. However, presented assessment of reservoir discharge here was quite arbitrary. Furthermore, taking into account the significant influence on hydrogeothermal parameters of local fracture phenomena, the estimates of the reservoir discharge conducted on a regional scale, e.g., according to [2,6,7], do not show local conditions. Reinterpretation of well-logs data in prospective zones should mainly concern the assessment of the thickness of groundwater horizons with an attempt to identify fractured zones (if possible), because the thickness of groundwater horizons is among the main parameters for the assessment discharge of the aquifer (according to the Darcy-Dupuit formula). This formula also uses the hydraulic conductivity coefficient, which is usually determined in an average form because the measurements results refer to only a fragment of the stratigraphic column. Therefore, a multivariate assessment of discharge of wells would consist in adopting a wide range of its values (from minimum to maximum), bearing in mind that in the fracture zones its value would be high but at the same time difficult to assess. This type of analysis should be carried out mainly in relation to holes No. 27, 28, 36, 40, 44 and 32 (Figure 6). Due to the age and condition of these wells, the current repetition of some 
measurements is excluded. Summing up, it is likely that in all prospective zones, water flows would need to be stimulated if the complex were to be used for space heating purposes. In all these zones, the level of the free water table and the depression value during water exploitation remain significant problems (only in the Kraków-Bochnia zone and in the Miechów area, free outflows of water were observed in wells 17, 18, 20, 22 and 28, Figure 6). Hydrogeological studies carried out in the area of Ustron demonstrated that the free water table, situated at the depth of $60 \mathrm{~m}$, was lowered to $120 \mathrm{~m}$ below ground level during exploitation at a rate of only $6 \mathrm{~m}^{3} / \mathrm{h}$. Thus, not only the water temperature and flow rate affect the efficiency of a geothermal project; reservoir pressure conditions are a factor as well. A separate problem is the dependence of water temperature on the flow: for small flow rates, the temperature at the wellhead may be much lower than in the reservoir itself [33]. Additionally, the issue of water mineral content was not addressed here due to mainly the exploratory nature of this study. The high mineral content of thermal waters enables their use in balneotherapy; however, in the context of space heating, it necessitates the use of a second reinjection well to pump spent water back into the reservoir. Moreover, waters in the complex analyzed often show mineral content above $100 \mathrm{~g} / \mathrm{L}$ (Table 1), which may result in intensive corrosion and scaling and clogging processes within the installation [34,35]. However, on the other hand, such high water mineralization, can also be interesting for energy harvesting from the salinity gradient [36]. This solution is increasingly interesting nowadays. Jia et al. [37] pointed out that salinity energy stored as the salinity difference between saline and freshwater is a renewable resource and can be converted to electricity. Energy extraction from thermal, high mineralized water is possible in pressure retarded osmosis (PRO), reverse electrodialysis (RED) or capacitive mixing (CAPMIX) processes [38]. For this reason, the search for obtaining thermal waters is an important direction of research to meet the needs of district heating as well as the possibility of obtaining energy in other innovative technological processes.

\section{Conclusions}

The Carboniferous-Devonian complex analyzed, which is situated in the part of Silesian-Kraków region, still has not been properly examined in hydrogeological terms. This is due, among other things, to the fact that for many years, studies in the Upper Silesian Basin focused mainly on the Upper Carboniferous complex (hard coal mining), and in the remaining area they focused on oil exploration within the Carpathian flysch, Cretaceous and Jurassic structures.

The prospective zones presented here are, therefore, of indicative nature only, as their identification has been based on limited data. The most reliable locations of prospective zones are in the Bielsko region and in the Proszowice-Bochnia-Brzesko zone. In the Bielsko region, it is due to the greater amount of available data as a result the continuous interest of oil industry in the zone [29], and the balneotherapeutic potential of Devonian waters (Ustroń). On the other hand, in the Proszowice-Brzesko-Bochnia zone, the need to explore and develop the Grobla-Mniszów-Pławowice gas and oil fields in Jurassic and Cenomanian formations resulted in over 100 informative wells being drilled, including some that reached Paleozoic formations. As geothermal water-bearing horizons within the well may occur at very different depths (difficulty in assessing temperatures) and achievable flow rates are difficult to predict, it appears premature to try to determine the energy resources available at this stage of complex recognition.

Summing up, the presented analyses and their results require further corrections, modifications and clarifications. They are not unambiguous (in some places, a question mark was placed on the map when the forecast was doubtful), but they represent an initial stage of work aimed at the exploitation and use of Carboniferous-Devonian waters for recreation and balneotherapy as well as for space heating purposes. The standard conclusion is that only new wells drilled in the zones identified will make it possible to verify the forecasts presented and allow the assessment of energy resources.

Author Contributions: Conceptualization, A.B. and R.S.; methodology, A.B.; validation, A.B., M.M. and B.T.; formal analysis, A.B.; investigation, B.T.; resources, R.S.; writing-original draft preparation, M.M. and B.T.; funding acquisition, B.T. All authors have read and agreed to the published version of the manuscript. 
Funding: This research was funded by Mineral and Energy Economy Research Institute, Polish Academy of Sciences statutory work and by the Polish National Centre for Research and Development-grant number POLTUR2/1/2017.

Conflicts of Interest: The authors declare no conflict of interest.

\section{References}

1. Poprawa, D.; Nemcok, J. (Eds.) Geological Atlas of the Western Outer Carpathians and Their Foreland; PIG: Warsaw, Poland; GUDS: Bratislava, Slovakia; UUG: Praha, Czech Republic, 1989.

2. Górecki, W. (Ed.) Atlas of Geothermal Resources of Paleozoic Formation in the Polish Lowlands; AGH-UST: Kraków, Poland, 2006.

3. Górecki, W. (Ed.) Atlas of Geothermal Resources of Mesozoic Formation in the Polish Lowlands; AGH-UST: Kraków, Poland, 2006.

4. Sowiżdżał, A.; Górecki, W.; Hajto, M. Geological conditions of geothermal resource occurrences in Poland. Geol. Q. 2020, 64, 185-196. [CrossRef]

5. Sowiżdżał, A. Geothermal energy resources in Poland-Overview of the current state of knowledge. Renew. Sustain. Energy Rev. 2018, 4020-4027. [CrossRef]

6. Górecki, W. (Ed.) Geothermal Atlas of the Carpathian Foredeep; AGH-UST: Kraków, Poland, 2012.

7. Górecki, W. (Ed.) Atlas of Geothermal Waters and Energy Resources in the Western Carpathians; AGH-UST: Kraków, Poland, 2006.

8. Barbacki, A.; Bujakowski, W.; Pająk, L. Atlas of Geothermal Water Reservoirs in Małopolska; MEERI PAS: Kraków, Poland, 2006.

9. Saran, E.; Barbacki, A. Geothermal characteristics of geological complexes in the Krakow Region. Pol. J. Environ. Stud. 2015, 15, 33-36.

10. Barbacki, A. The aquifers of geothermal waters of the Miechów trough and central part of the Carpathian foredeep. In Series: Studia, Rozprawy, Monografie 125; MEERI PAS: Kraków, Poland, 2004.

11. Barbacki, A. Paleozoic reservoirs at the basement of the Cracow-Kielce region (Southern Poland): Possibilities of utilising geothermal energy. Prz. Geol. 2004, 52, 243-252.

12. Barbacki, A.; Kazanowska, A. Middle Jurassic geothermal formation in central part of the Carpathian Foredeep and neighboring areas (Southern Poland). Prz. Geol. 2001, 49, 894-900.

13. Bujakowski, W.; Barbacki, A. Possibilities of geothermal energy utilization in Bochnia-Brzesko area (S Poland). Prz. Geol. 2007, 55, 258-262.

14. Bujakowski, W.; Barbacki, A. Potential for geothermal development in Southern Poland. Geothermics 2004, 33, 383-395. [CrossRef]

15. Różkowski, A. An occurrence conditions of geothermal waters within the Upper Silesian Massif. Geol. Explor. Technol. Geotherm. Sustain. Dev. 1996, 3-4, 9-12.

16. Różkowski, A. Geological environment of geothermal waters in the productive carboniferous formation in the Upper Silesian Coal Basin. Geol. Explor. Technol. Geotherm. Sustain. Dev. 2001, 5, 51-62.

17. Różkowski, A. The Development of the Water Exchange Zone in the Upper Silesian Coal Basin on the Groundwater Isotope Composition; Reiche, C., Ed.; Freiburger Institut for Musikermedizin: Breisgau, Germany, 1986; Volume 417, pp. 137-142.

18. Karwasiecka, M. The geothermal field of the Upper Silesian Coal Basin. Geol. Explor. Technol. Geotherm. Sustain. Dev. 2001, 5, 41-49.

19. Karwasiecka, M. Geothermal prospects of the Upper Silesian Basin. Geol. Explor. Technol. Geotherm. Sustain. Dev. 1996, 3-4, 28-32.

20. Karwasiecka, M. Geothermal Atlas of the Upper Silesian Coal Basin; Cartographic Publishing House of the Polish Ecological Agency: Warszawa, Poland, 1996.

21. Małolepszy, Z. Geosynoptic model of geothermics in the Upper Silesian Coal Basin. Geol. Explor. Technol. Geotherm. Sustain. Dev. 2000, 3, 3-35.

22. Małolepszy, Z. Geothermal resources within hard coal mines, Upper Silesian Coal Basin. Geol. Explor. Technol. Geotherm. Sustain. Dev. 1999, 3, 57-69.

23. Trzepierczyński, J. Geothermal energy in deep boreholes in the Upper Silesian Coal Basin; the abilities of utilization. Geol. Explor. Technol. Geotherm. Sustain. Dev. 2001, 5, 95-105. 
24. Chowaniec, J.; Poprawa, D. Thermal waters of the Polish part of the Carpathians. Prz. Geol. 1998, 46, 770-774.

25. Bukowy, S. Wariscian Structures of Silesian-Kraków Region; Scientific Works of the University of Silesia; University of Silesia: Katowice, Poland, 1984; Volume 691, pp. 1-75.

26. Bukowy, S. On views about geological structure of Paleozoic in Kraków-Lubliniec Region. Geol. Explor. Technol. Geotherm. Sustain. Dev. 1997, 1-2, 15-24.

27. Bujakowski, W.; Tomaszewska, B.; Miecznik, M. The Podhale geothermal reservoir simulation for long-term sustainable production. Renew. Energy 2016, 99, 420-430. [CrossRef]

28. Konior, K. Reservoir parameters of crystalinic basement and paleozoic of the southern edge of the GZW in the Bielsko-Mogilany area. Geofiz. Geol. Naft. 1970, 9-10, 247-262.

29. Konior, K. General Palaeostructural Analysis and Characteristics of Reservoir Rocks of the Rzeszotary Uplift and Adjacent Areas; Commission of Geological Sciences of the Polish Academy of Sciences, Geological Works: Kraków, Poland, 1978; Volume 112, pp. 3-63.

30. Baran, U.; Jawor, E.; Jawor, W. Geological diagnosis and results of hydrocarbon exploration work in the western part of the Polish Carpathians. Prz. Geol. 1997, 45, 66-75.

31. Jurkiewicz, H.; Maszońska, D.; Szczerba, A.; Woiński, J. Profiles of Deep Boreholes of the Geological Institute: Węrzynów IG-1; Geological Publishing IG: Warszawa, Poland, 1973; Volume 7.

32. Moryc, W. (Ed.) Drilling Catalog of Petroleum Mining in Poland: 1970-1976 Vol. 1/3-5; Geological Publishing: Warszawa, Poland, 1976.

33. Wachowicz-Pyzik, A.; Sowiżdżał, A.; Pająk, L.; Ziółkowski, P.; Badur, J. Assessment of the effective variants leading to higher efficiency for the geothermal doublet, using numerical analysis-case study from Poland (Szczecin Trough). Energies 2020, 13, 2174. [CrossRef]

34. Tomaszewska, B.; Pajak, L. Dynamics of clogging process in injection wells used to pump highly mineralized thermal water into the sandstone structures lying under the Polish Lowlands. Arch. Environ. Prot. 2012, 38, 105-117. [CrossRef]

35. Tomaszewska, B.; Pajak, L. Reinjection of cooled water back into a reservoir. In Geothermal Water Management; Bundschuh, J., Tomaszewska, B., Eds.; Taylor \&Francis Group: London, UK, 2018; pp. 1-104.

36. Bryjak, M.; Kabay, N.; Guler, E.; Tomaszewska, B. Concept for Energy Harvesting from the Salinity Gradient on the Basis of Geothermal Water; WEENTECH Proceedings in Energy 4; World Energy and Environment Technology Ltd.: Coventry, UK, 2018; pp. 88-96.

37. Jia, Z.; Wang, B.; Song, S.; Fan, Y. Blue energy: Current technologies for sustainable power generation from water salinity gradient. Renew. Sustain. Energy Rev. 2014, 31, 91-100. [CrossRef]

38. Brogioli, D.; Ziano, R.; Rica, R.A.; Salerno, D.; Mantegazza, F. Capacitive mixing for the extraction of energy from salinity differences: Survey of experimental results and electrochemical models. J. Colloid Interface Sci. 2013, 407, 457-466. [CrossRef] [PubMed]

Publisher's Note: MDPI stays neutral with regard to jurisdictional claims in published maps and institutional affiliations.

(C) 2020 by the authors. Licensee MDPI, Basel, Switzerland. This article is an open access article distributed under the terms and conditions of the Creative Commons Attribution (CC BY) license (http://creativecommons.org/licenses/by/4.0/). 